\title{
Evidence for the pulsatile release of PGF-2 $\alpha$ inducing the release of ovarian oxytocin during luteolysis in the ewe*
}

\author{
L. G. Moore†, V. J. Choy, R. L. Elliot $\ddagger$ and W. B. Watkins \\ Postgraduate School of Obstetrics and Gynaecology, University of Auckland, Auckland, \\ New Zealand
}

\begin{abstract}
Summary. Frequent blood samples were removed from a utero-ovarian vein, a jugular vein and a femoral artery of 5 ewes during luteolysis. Analysis of these samples for oxytocin-associated neurophysin revealed a significant venous-arterial difference across the ovary and uterus but not across the head. This occurred during the pulsatile surges as well as when levels were basal and confirms the corpus luteum as a major source of the pulsatile surges of oxytocin-associated neurophysin and oxytocin that occur during CL regression and also of the elevated luteal phase concentrations of both hormones. The pulsatile surges of oxytocin-associated neurophysin measured in the utero-ovarian vein were accompanied by the release of an approximately equimolar amount of oxytocin.

The concentration of PGF- $2 \alpha$ in the utero-ovarian vein samples began to increase before the levels of oxytocin and oxytocin-associated neurophysin started to increase. This suggests that uterine PGF- $2 \alpha$ initiates the release of ovarian oxytocin and oxytocin-associated neurophysin during luteolysis in the ewe.
\end{abstract}

\section{Introduction}

The corpus luteum (CL) of the sheep contains high concentrations of oxytocin-like immunoreactive material (Wathes \& Swann, 1982; Watkins, 1983) which is secreted together with neurophysin I/II (the oxytocin-associated neurophysin) into the ovarian vein (Flint \& Sheldrick, 1982; Watkins, Moore, Flint \& Sheldrick, 1984b). During the luteal phase of the oestrous cycle in the ewe, oxytocin and oxytocin-associated neurophysin concentrations are elevated in the peripheral circulation (Sheldrick \& Flint, 1981; Webb, Mitchell, Falconer \& Robinson, 1981; L. G. Moore, W. B. Watkins \& R. J. Fairclough, unpublished observation) and are released in pulsatile peaks during luteolysis (Fairclough et al., 1980; Flint \& Sheldrick, 1983). Venous-arterial differences of oxytocin and oxytocin-associated neurophysin concentrations across the ovary in anaesthetized ewes (Flint \& Sheldrick, 1982; Watkins et al., 1984b) and higher levels of oxytocin in the vena cava than in the jugular vein of cows during the luteal phase (Walters, Schams \& Schallenberger, 1984) suggest that the elevated luteal-phase values of oxytocin originate from the CL. This conclusion is supported by the observations that the luteal-phase oxytocin concentration is positively correlated with the number of CL present (Schams, Lahlou-Kassi \& Glatzel, 1982; Schams, Prokopp \& Barth, 1983) and that the plasma oxytocin concentration can be reduced by cloprostenol-induced CL regression (Flint \& Sheldrick, 1983). It is not known whether the pulsatile surges of oxytocin and oxytocinassociated neurophysin during CL regression originate from the CL (Flint \& Sheldrick, 1983) or from the posterior pituitary gland (Fairclough et al., 1980; Mitchell, Kraemer, Brennecke \& Webb, 1982).

\footnotetext{
*Reprint requests to Dr W. B. Watkins.

†Present address: Wallaceville Animal Research Centre, Upper Hutt, New Zealand.

† Present address: Surgical Laboratory, Green Lane Hospital, Auckland, New Zealand.
} 
We have suggested that pulsatile surges of oxytocin induce the release of uterine prostaglandin (PG) F-2 $\alpha$ which in turn causes CL regression (Fairclough et al. (1980). This is supported by the observation that coincident surges of the PGF-2 $\alpha$ metabolite, 13,14-dihydro-15-keto-PGF-2 $\alpha$ (PGFM) and oxytocin-associated neurophysin (Fairclough et al., 1980) or oxytocin (Flint \& Sheldrick, 1983) occur when hourly plasma samples are taken during luteolysis. Further support for oxytocin causing uterine PGF-2 $\alpha$ release during luteolysis is given by the fact that exogenous oxytocin can stimulate the release of uterine PGF- $2 \alpha$, particularly at the end of the cycle when there is a large increase in the number of endometrial oxytocin receptors (Roberts, Barcikowski, Wilson, Skarnes \& McCracken, 1975; Roberts, McCracken, Gavagan \& Soloff, 1976; Roberts \& McCracken, 1976). An alternative inter-relationship between oxytocin and PGF-2 $\alpha$ within the utero-ovarian systems is indicated from the finding that cloprostenol (an analogue of PGF-2 $\alpha$ ) can cause the release of oxytocin and its associated neurophysin into the utero-ovarian vein (Flint $\&$ Sheldrick, 1982; Watkins et al., 1984b).

The present experiments were undertaken to determine whether the pulsatile surges of oxytocinassociated neurophysin and oxytocin originate from the posterior pituitary or the corpus luteum and to examine the temporal relationship between oxytocin and PGF- $2 \alpha$ plasma concentrations during a pulsatile peak.

\section{Materials and Methods}

Animals. The oestrous cycles of 5 Romney ewes were synchronized by insertion, for 12 days, of intravaginal sponges containing $60 \mathrm{mg} 6 \alpha$-methyl-17 $\alpha$-acetoxyprogesterone. The day the sponge was removed was denoted as Day -2 of the oestrous cycle. On Day 10 or Day 12 of the oestrous cycle, the ewes were anaesthetized by an epidural administration of $0.25 \%$ bupivacaine hydrochloride and 1\% lignocaine (Astra Chemicals, Sydney, Australia) and catheters were inserted into a utero-ovarian vein draining an ovary containing a CL. The operative procedure followed was similar to that described by Flint \& Sheldrick (1983) with the catheter inserted down-stream into the ovarian vein and the top of the catheter being placed about $100 \mathrm{~mm}$ past the junction of the uterine and ovarian veins. Jugular vein and femoral artery catheters were also introduced.

Blood $(1.5 \mathrm{ml})$ was collected in tubes containing EDTA every $30 \mathrm{~min}$ for $12 \mathrm{~h}$ from all 3 catheters and about every $6 \mathrm{~min}$ for $8 \mathrm{~h}$ from the utero-ovarian catheter on Days 13, 14 and 15 of the oestrous cycle. The samples were collected on ice, centrifuged within $20 \mathrm{~min}$ and stored at $-20^{\circ} \mathrm{C}$ until assayed.

Hormone assays. Plasma concentrations of oxytocin-associated neurophysin were determined using a radioimmunoassay (RIA) based upon that previously described (Moore \& Watkins, 1983). The assay cross-reacts $2 \cdot 5 \%$ with ovine neurophysin-III, the vasopressin-associated neurophysin. Amino acid and analysis of the purified standards of ovine neurophysin-I, -II and -III, prepared according to Moore \& Watkins, (1981), revealed that they consisted of 48, 61, 64\% protein, respectively, which is comparable to results found for human neurophysins (North, LaRochelle, Melton \& Mills, 1980). The quantities measured by RIA have been corrected to account for this discrepancy. The antiserum was raised against ovine neurophysin-II and neurophysin-I was iodinated as described previously (Moore $\&$ Watkins, 1983). Each assay tube contained $300 \mu$ antiserum to neurophysin-II at a dilution of $1: 10000,2 \mu \mathrm{l}$ non-immunized rabbit serum and $100 \mu \mathrm{l}$ plasma or $100 \mu$ l of the reference standard neurophysin-I dissolved in phosphate buffer (Moore \& Watkins, 1983). After incubation for 3 days at $4^{\circ} \mathrm{C}, 50 \mu{ }^{125} \mathrm{I}$-labelled neurophysin-I (120 pg, $\sim 20000$ c.p.m.) were added and the incubation was continued for a further 2 days at $4^{\circ} \mathrm{C}$. Separation of antibody-bound and free ${ }^{125} \mathrm{I}$-labelled neurophysin-I was achieved by the addition of sheep anti-rabbit $\gamma$-globulin antiserum $(1.5 \mathrm{ml})$ at a dilution of $1: 300$ in assay buffer containing $3 \%$ $(\mathrm{w} / \mathrm{v})$ polyethylene glycol. After incubating overnight at $4{ }^{\circ} \mathrm{C}$ the tubes were centrifuged at $2000 \mathrm{~g}$ for $35 \mathrm{~min}$, and the radioactivity of the precipitate was counted. 
The assay had a sensitivity of $63 \mathrm{pg} / \mathrm{ml}$ and a range from $330 \mathrm{pg} / \mathrm{ml}(80 \%$ of the zero standard) to $5700 \mathrm{pg} / \mathrm{ml}(20 \%$ of the zero standard). Intra-assay and inter-assay variations were $5 \cdot 7 \%$ and $5.3 \%$ respectively for a plasma sample which had a mean value of $1.07 \mathrm{ng} / \mathrm{ml}(n=13)$. Parallelism between standard and unknowns was achieved when samples were diluted or had additional neurophysin added to them.

PGF-2 $a$ was measured using the RIA described by Liggins, Campos, Roberts \& Skinner (1980) adapted for plasma samples. Each assay tube contained: $200 \mu \mathrm{l}$ PGF- $2 \alpha$ antiserum diluted $1: 4000$ in Tris- $\mathrm{HCl}$ buffer ( $\mathrm{pH} \mathrm{8.0);} 50 \mu \mathrm{l}$ utero-ovarian vein plasma; $50 \mu \mathrm{l}$ Tris- $\mathrm{HCl}$ buffer ( $\mathrm{pH} \mathrm{8.0)} \mathrm{or}$ $50 \mu$ l plasma obtained from a hysterectomized ewe; standard PGF- $2 \alpha$ in $50 \mu \mathrm{l}$ Tris $-\mathrm{HCl}$ buffer. After incubation for $4 \mathrm{~h}$ at $4^{\circ} \mathrm{C}, 50 \mu \mathrm{l}$ tritiated PGF-2 $\alpha$ (3000 c.p.m.) in Tris-HCl buffer were added and the mixture was incubated for a further $20 \mathrm{~min}$ at $4{ }^{\circ} \mathrm{C}$. Bound and free hormone were separated by the addition of $2.0 \mathrm{ml} 60 \%(\mathrm{w} / \mathrm{v})$ ammonium sulphate $(\mathrm{pH} 8.0)$ and centrifugation for $15 \mathrm{~min}$ at $1500 \mathrm{~g}$. The precipitate was dissolved in $0.8 \mathrm{ml}$ distilled water and transferred to a scintillation vial for measurement of radioactivity. The RIA had a sensitivity of $0.1 \mathrm{ng} / \mathrm{ml}$ and a range from $0.5 \mathrm{ng} / \mathrm{ml}(80 \%$ of zero standard) to $13 \mathrm{ng} / \mathrm{ml}(20 \%$ of the zero standard). Intra-assay and interassay variations were $7.9 \%$ and $6.1 \%$ respectively for a plasma sample which had a mean value of $1.41 \mathrm{ng}-\mathrm{ml}(n=4)$. Parallelism between standard and unknown was achieved when samples were diluted or had additional PGF-2 $\alpha$ added to them. Plasma oxytocin assays were performed using the antiserum and protocol described by Robinson (1980). The intra- and inter-assay variation in the assay was $3.8 \%$ and $7 \cdot 4 \%$ respectively. Progesterone was measured using an RIA with ${ }^{125}$ I-labelled progesterone (RSL : Carson, California) but with plasma from an ovariectomized sheep added to the reference standards.

Analyses. Statistical evaluation of the venous-arterial differences was performed using the Mann-Whitney test.

\section{Results}

Concentrations of oxytocin-associated neurophysin in utero-ovarian vein plasma collected at 30-min intervals from 5 ewes between Days 13 and 15 of the oestrous cycle (mean $1.98 \mathrm{ng} / \mathrm{ml}$ ) were significantly higher $(P<0.0001)$ than the arterial values (mean $0.96 \mathrm{ng} / \mathrm{ml})$. Jugular vein concentrations (mean $0.97 \mathrm{ng} / \mathrm{ml}$ ) were not significantly different from the arterial values.

Many pulses of oxytocin-associated neurophysin were observed in the utero-ovarian plasma but these were classified as pulsatile peaks only when coordinate increases in the utero-ovarian vein, jugular vein and femoral artery oxytocin-associated neurophysin were observed. Four pulsatile peaks were observed in 3 of the ewes examined, with these occurring just before or when the plasma progesterone concentration was decreasing.

During the pulsatile peaks, utero-ovarian oxytocin-associated neurophysin concentrations (mean $4.33 \mathrm{ng} / \mathrm{ml}$ ) were significantly higher $(P<0.001)$ than the arterial values (mean $1.56 \mathrm{ng} / \mathrm{ml}$ ). No significant difference was found between jugular vein (mean $1.60 \mathrm{ng} / \mathrm{ml}$ ) and femoral artery concentrations of oxytocin-associated neurophysin (Fig. 1).

Analysis of the pulsatile peak samples taken at 6-min intervals revealed that there was a concurrent release of oxytocin and oxytocin-associated neurophysin (Fig. 1). During the pulsatile peaks the hormones were released in a mean molar ratio of $1: 1 \cdot 2(n=4)$.

Utero-ovarian vein plasma PGF- $2 \alpha$ concentrations increased during the pulsatile peaks an average of $17 \mathrm{~min}$ before the levels of oxytocin began to rise to form a peak of sufficient magnitude and duration to cause an increase in systemic plasma concentrations of oxytocin-associated neurophysin (Fig. 2). 

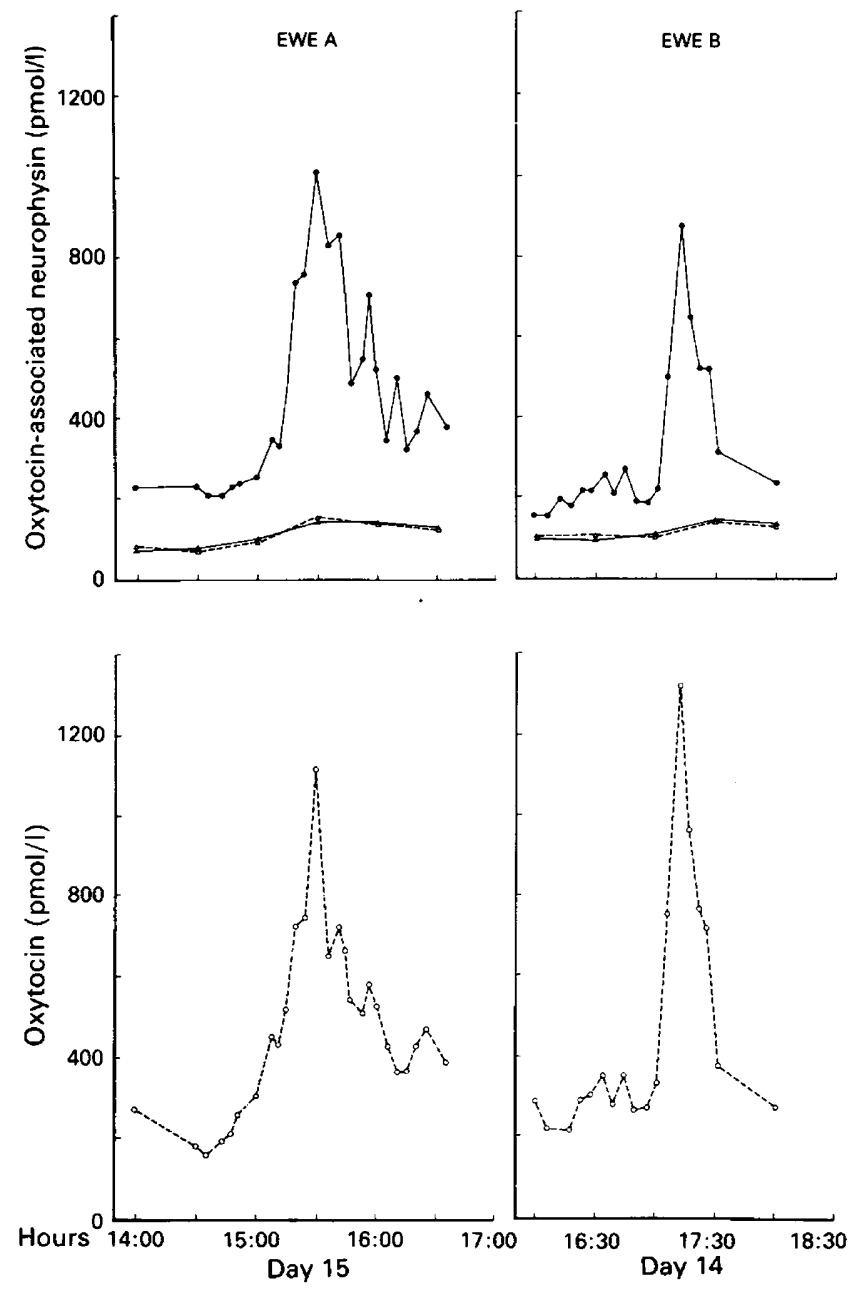

Fig. 1. Plasma concentrations of oxytocin-associated neurophysin in the femoral artery $(\Delta-\Delta)$, jugular vein $(\triangle--\Delta)$ and utero-ovarian vein $(-\infty)$ and of oxytocin in the utero-ovarian vein $(\mathrm{O}---\mathrm{O})$ during two pulsatile peaks in two ewes (A and $\mathrm{B}$ ) on Days 15 and 14 , respectively of the oestrous cycle.

\section{Discussion}

Our present results show that, during the late luteal phase, pulsatile peak concentrations of oxytocin-associated neurophysin in the utero-ovarian vein exceed arterial levels and that no venous-arterial difference was found across the head. This indicates that the $\mathrm{CL}$ is the source of the pulsatile peaks of oxytocin and oxytocin-associated neurophysin that occur during luteolysis.

It is unlikely that the elevated utero-ovarian concentrations of oxytocin and oxytocin-associated neurophysin do not originate from the CL because, relative to the CL, non-luteal ovarian tissues and uterine tissues contain little oxytocin (Flint \& Sheldrick, 1983). Further support for a luteal origin of the elevated utero-ovarian oxytocin and oxytocin-associated neurophysin values comes from the work of Sheldrick \& Flint (1984). They found that, in anaesthetized ewes, basal and 

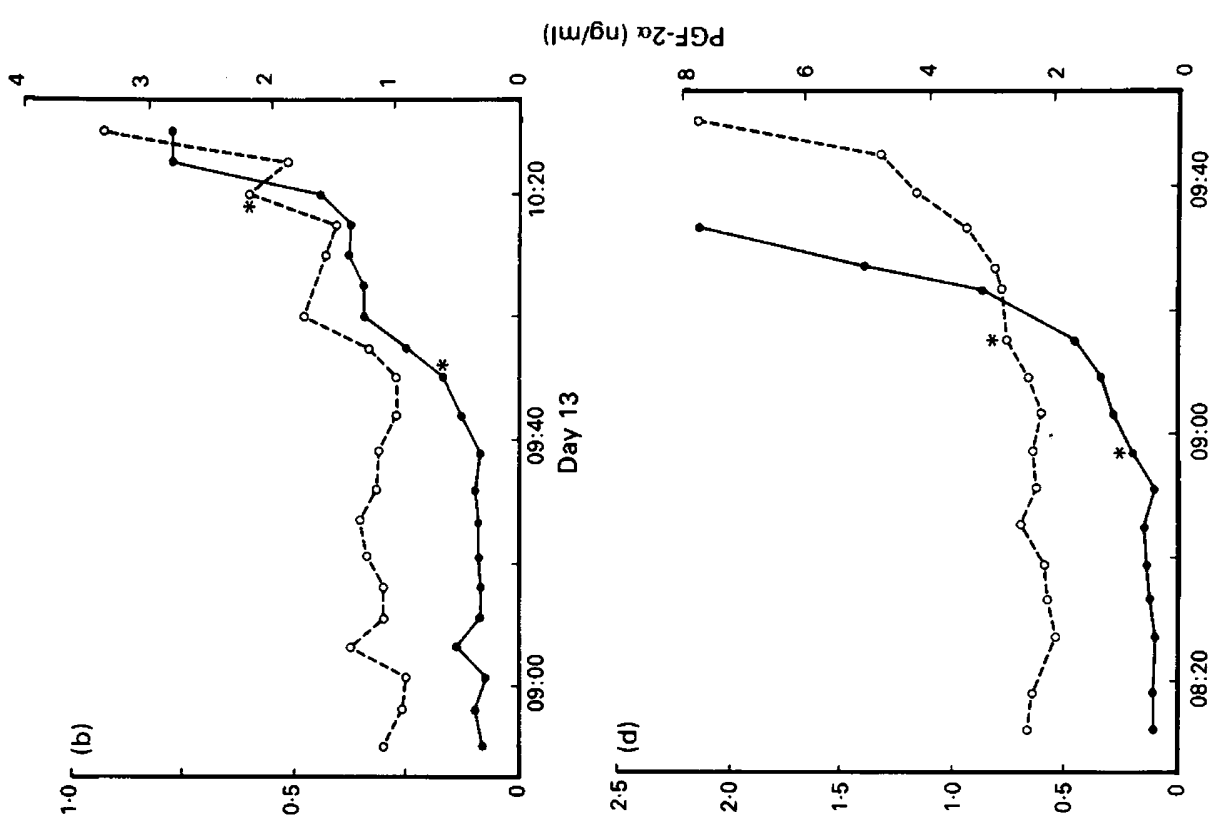

$\stackrel{4}{5}$

(ןw/6u) $x z-\unlhd 9 d$
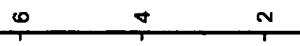

$\infty$
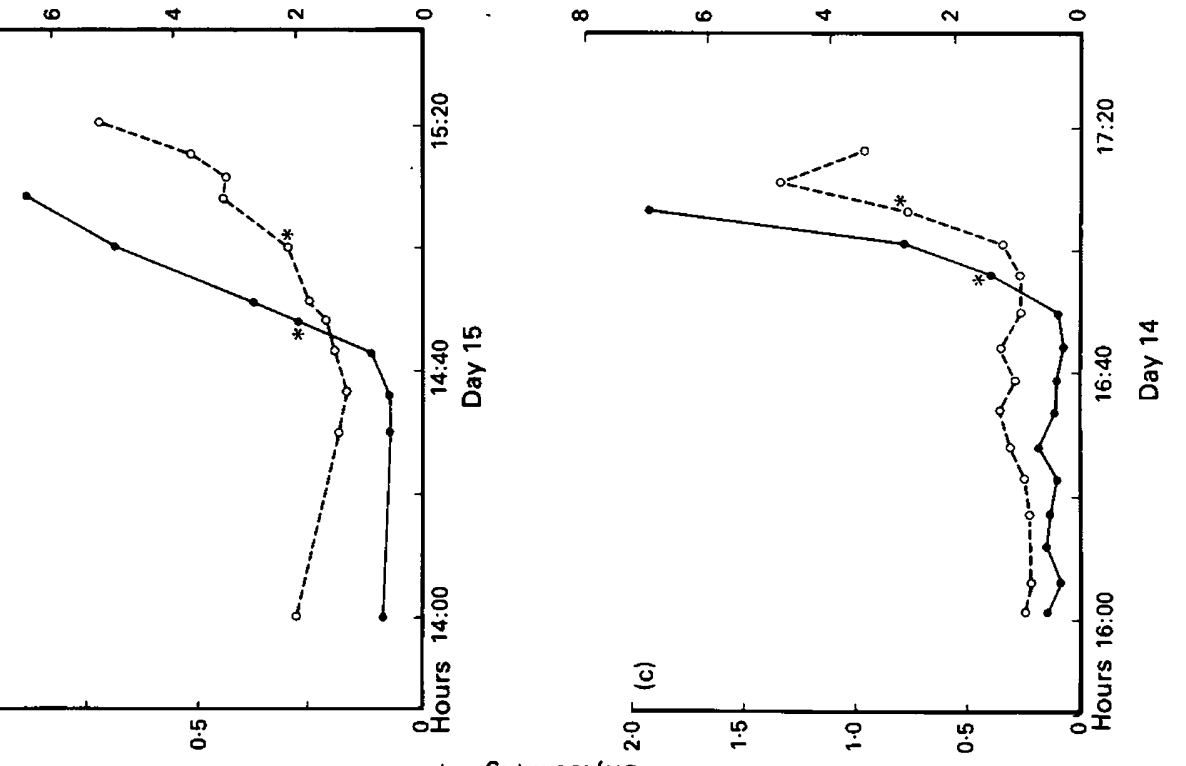

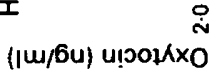

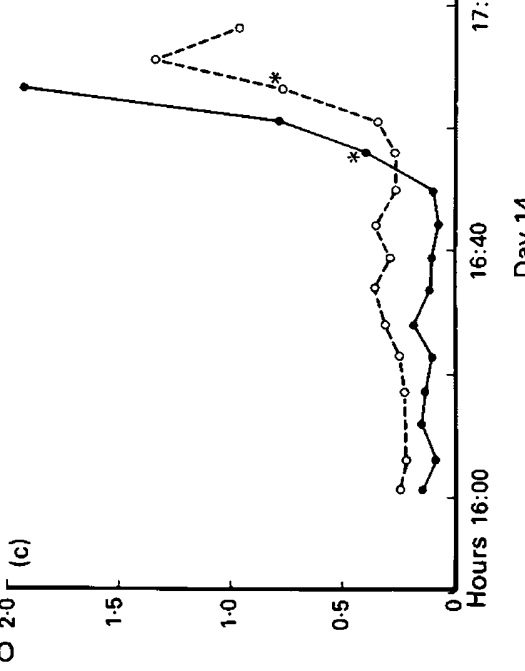

올

궁

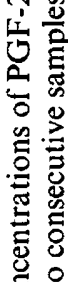


cloprostenol-stimulated ovarian vein concentrations of oxytocin were higher than those in the jugular vein or uterine artery. These differences were only observed when the ovary contained a CL (Flint \& Sheldrick, 1983).

We have previously reported that oxytocin and oxytocin-associated neurophysin were released in approximately equimolar ratios into the utero-ovarian vein after cloprostenol stimulation of ewes (Watkins et al., 1984b). We have now shown that during the late luteal phase of the sheep oestrous cycle spontaneous pulsatile release of exytocin into the ovarian vein is accompanied by the release of an approximately equimolar amount of oxytocin-associated neurophysin.

That PGF- $2 \alpha$ is released into the utero-ovarian vein before either oxytocin or oxytocinassociated neurophysin (Fig. 2) would support the proposal that PGF-2 $\alpha$ induces the pulsatile release of oxytocin and oxytocin-associated neurophysin during luteolysis in the sheep. This is consistent with the inhibition of pulsatile oxytocin-associated neurophysin release in ewes (Watkins, Moore, Fairclough, Peterson \& Tervit, 1984a) and oxytocin release in goats (Cooke \& Homeida, 1984) after systemic treatment of the animals with the prostaglandin inhibitor indomethacin.

Ovarian oxytocin or PGF-2 $\alpha$ does not appear to be necessary for the release of uterine PGF- $2 \alpha$ because the pulsatile release of PGFM has been observed in ovariectomized ewes with oestrogen replacement (Lye, Sprague \& Challis, 1983). In cows that have received exogenous progesterone, luteal oxytocin or PGF-2 $\alpha$ do not seem to be involved in the pulsatile release of PGFM which occurs after the CL has regressed (Smith, Fairclough \& Peterson, 1979; Kindahl, Edqvist \& Lindell, 1980). However, until oxytocin or oxytocin-associated neurophysin has been measured in animals, without CL, that are releasing PGFM in a pulsatile manner, the possibility that oxytocin is being released from the other sites cannot be excluded.

A previous objection to PGF- $2 \alpha$ causing oxytocin release during luteolysis was that PGF- $2 \alpha$ could not reach the brain to cause oxytocin release because it is rapidly metabolized by the lungs (Piper, Vane \& Wyllie, 1970; Davis, Fleet, Harrison \& Maule Walker, 1980; Fairclough et al., 1980). Our present results, which suggest an ovarian source of the oxytocin, overcome this objection because PGF- $2 \alpha$ can reach the CL by the countercurrent mechanism operating between the utero-ovarian vein and the ovarian artery (McCracken et al., 1972). However, it is still possible that a PGF- $2 \alpha$ metabolite may cause oxytocin release by a systemic route.

Oxytocin appears to be important for CL regression because immunization against oxytocin prolongs the luteal phase (Sheldrick, Mitchell \& Flint, 1980; Schams et al., 1983). The findings that exogenous oxytocin does not cause $\mathrm{CL}$ regression in goats treated with the prostaglandin synthetase inhibitor meclofenamate (Cooke \& Knifton, 1981) or in hysterectomized cows (Armstrong \& Hansel, 1959) and sheep (Hatjiminaoglou, Alifakiotis \& Zervas, 1979) and that oxytocin can stimulate PGF- $2 \alpha$ release, particularly at the end of the oestrous cycle when there is a large increase in the number of uterine oxytocin receptors (Roberts et al., 1975, 1976; Roberts \& McCracken, 1976), suggest that the role of oxytocin in luteolysis involves the release of uterine PGF- $2 \alpha$.

However, the present results, which show that PGF- $2 \alpha$ increases before oxytocin at the beginning of a pulsatile peak, indicate that an increase in plasma oxytocin does not initiate the pulsatile release of PGF-2 $\alpha$. McCracken, Schramm \& Okulicz (1984) have suggested that basal levels of oxytocin interact with uterine oxytocin receptors, thus initiating PGF- $2 \alpha$ release. The ability of oxytocin to provide positive feedback on PGF- $2 \alpha$ release and cause down-regulation of uterine oxytocin receptors suggests that oxytocin may fine-tune the PGF-2 $\alpha$ pulses so that they can efficiently cause CL regression (Schramm, Bovaird, Glew, Schramm \& McCracken, 1983).

Whether luteal oxytocin also has a role in modulating the release of hormones from other endocrine tissues during the oestrous cycle should be the subject of further investigation (Donaldson, Hansel \& Van Vleck, 1965; Tan, Tweedale \& Biggs, 1982; Froehlick, Ben-Jonathan \& Neill, 1984).

We thank Dr I. C. A. F. Robinson for providing samples of rabbit anti-oxytocin serum. This study was supported by the Medical Research Council of New Zealand. 


\section{References}

Armstrong, D.T. \& Hansel, W. (1959) Alteration of the bovine estrous cycle with oxytocin. J. Dairy Sci. 42, 533-542.

Cooke, R.G. \& Homeida, A.M. (1984) Delayed luteolysis and suppression of the pulsatile release of oxytocin after indomethacin treatment in the goat. Res. vet. Sci. 36, 48-51.

Cooke, R.G. \& Knifton, A. (1981) Oxytocin-induced oestrous in the goat. Theriogenology 16, 95-97.

Davis, A.J., Fleet, I.R., Harrison, F.A. \& Maule Walker, F.M. (1980) Pulmonary metabolism of prostaglandin $F_{2} \alpha$ in the conscious and non-pregnant ewe and sow. J. Physiol., Lond. 301, 86P, Abstr.

Donaldson, L.E., Hansel, W. \& Van Vleck, L.D. (1965) Luteotropic properties of luteinizing hormone and nature of oxytocin induced luteal inhibition in cattle. J. Dairy Sci. 48, 331-337.

Fairclough, R.L., Moore, L.G., McGowan, L.T., Peterson, A.J., Smith, J.F., Tervit, H.R. \& Watkins, W.B. (1980) Temporal relationship between plasma concentrations of 13,14-dihydro-15-keto-prostaglandin $\mathbf{F}$ and neurophysin $\mathbf{I} / \mathbf{I I}$ around luteolysis in sheep. Prostaglandins 20, 199-208.

Flint, A.P.F. \& Sheldrick, E.L. (1982) Ovarian secretion of oxytocin is stimulated by prostaglandin. Nature, Lond. 297, 587-588.

Flint, A.P.F. \& Sheldrick, E.L. (1983) Evidence for a systemic role for ovarian oxytocin in luteal regression in sheep. J. Reprod. Fert. 67, 215-225.

Froehlick, J.C., Ben-Jonathan, N. \& Neill, M.A. (1984) Posterior pituitary involvement in the control of luteinizing hormone and prolactin secretion during the estrous cycle. Endocrinology 114, 1059-1064.

Hatjiminaoglou, I., Alifakiotis, T. \& Zervas, N. (1979) The effect of exogenous oxytocin on estrous cycle length and corpus luteum lysis in ewes. Annls Biol. anim. Biochim. Biophys. 19, 355-365.

Kindahl, H., Edqvist, L.-E. \& Lindell, J.-O. (1980) On the control of prostaglandin release during the bovine estrous cycle. Adv. Prostaglandin Thomboxane Res. 8, $1351-1355$.

Liggins, G.C., Campos, G.A., Roberts, C.M. \& Skinner, S.J. (1980) Production rates of prostaglandin F, 6keto-PGF $F_{1}$ and thromboxane $B_{2}$ by perfused human endometrium. Prostaglandins 19, $461-477$.

Lye, S.J., Sprague, C.L. \& Challis, J.R.C. (1983) Modulation of ovine myometrial activity by estradiol-17ß. The possible involvement of prostaglandins. Can J. Physiol. Pharmacol. 61, 729-735.

McCracken, J.A., Carison, J.C., Glew, M.E., Goding, J.R., Baird, D.T., Green, K. \& Samuelsson, B. (1972) Prostaglandin $\mathrm{F}_{2 a}$ identified as a luteolytic hormone in sheep. Nature, New Biol. 238, 129-134.

McCracken, J.A., Schramm, W. \& Okulicz, W.C. (1984) Hormone receptor control of pulsatile secretion of $\mathrm{PGF}_{2 a}$ from the ovine uterus during lteolysis and its abrogation in early pregnancy. Anim. Reprod. Sci. 7, 31-55.

Mitchell, M.D., Kraemer, D.L., Brennecke, S.P. \& Webb, R. (1982) Pulsatile release of oxytocin during the estrous cycle, pregnancy and parturition in sheep. Biol. Reprod. 27, 1169-1173.
Moore, L.G. \& Watkins, W.B. (1981) Purification of sheep neurophysins from whole pituitary glands and proposed relationships between neurophysin $-\mathbf{I}$, and -II and the neurohypophysial hormones. Neuropeptides 2, 75-88.

Moore, L.G. \& Watkins, W.B. (1983) Development of radioimmunoassays for ovine neurophysins. Correlation of neurophysin release with oxytocin- and vasopressin-related stimuli. Endocrinology 112, $113-120$.

North, W.G., LaRochelle, F.T., Melton, J. \& Mills, R.C. (1980) Isolation and partial characterization of two human neurophysins: and their use in the development of specific radioimmunoassays. J. clin. Endocr. Metab. 51, 844891 .

Piper, P.J., Vane, J.R. \& Wyllie, J.H. (1970) Inactivation of prostaglandins by the lungs. Nature, Lond. 225, 600-604.

Roberts, J.S. \& McCracken, J.A. (1976) Does prostaglandin $F_{2 a}$ released from the uterus by oxytocin mediate the oxytocic action of oxytocin? Biol. Reprod. 15, 457-463.

Roberts, J.S., Barcikowski, B., Wilson, L., Skarnes, R.C. \& McCracken, J.A. (1975) Hormonal and related factors affecting the release of prostaglandin $F_{2 a}$ from the uterus. J. Steroid Biochem. 6, 1091-1097.

Roberts, J.S., McCracken, J.A., Gavagan, J.E. \& Soloff, M.S. (1976) Oxytocin-stimulated release of prostaglandin $F_{2 a}$ from ovine endometrium in vitro. Correlation with estrous cycle and oxytocin-receptor binding. Endocrinology 99, 1107-1114.

Robinson, I.C.A.F. (1980) The development and evaluation of a sensitive and specific radioimmunoassay for oxytocin in unextracted plasma. J. Immunol. 1, $323-347$.

Schams, D., Lahlou-Kassi, A. \& Glatzel, P. (1982) Oxytocin concentrations in peripheral blood during the oestrous cycle and after ovariectomy in two breeds of sheep with low and high fecundity. J. Endocr. 92, 9-13.

Schams, D., Prokopp, S. \& Barth, D. (1983) The effect of active and passive immunization against oxytocin on ovarian cyclicity in ewes. Acta endocr., Copenh. 103, 337-344.

Sehramm, W., Bovaird, L., Glew, M.E., Schramm, G. \& McCracken, J.A. (1983) Corpus luteum regression included by ultra-low pulses of prostaglandin $F_{2 \alpha}$ Prostaglandins 26, 347-364.

Sheldrick, E.L. \& Flint, A.P.F. (1981) Circulating concentrations of oxytocin during the estrous cycle and early pregnancy in sheep. Prostaglandins 22, 631-636.

Sheldrick, E.L. \& Flint, A.P.F. (1984) Ovarian oxytocin and luteal function in the early pregnant sheep. Anim. Reprod. Sci. 7, 101-114.

Sheldrick, E.L., Mitchell, M.D. \& Flint, A.P.F. (1980) Delayed luteal regression in ewes immunized against oxytocin. J. Reprod. Fert. 59, 37-42.

Smith, J.F., Fairclough, R.J. \& Peterson, A.J. (1979) Plasma levels of progesterone, Provera, oestradiol$17 \beta$, and 13,14-dihydro-15-keto-prostaglandin $F$ in cows treated with Provera-impregnated intravaginal sponges. J. Reprod. Fert. 55, 359-364. 
Tan, G.J.S., Tweedale, R. \& Biggs, J.S.G. (1982) Effect of oxytocin on the bovine corpus luteum of early pregnancy. J. Reprod. Fert. 66, 75-78.

Walters, D.L., Schams, D., \& Schallenberger, E. (1984) Pulsatile secretion of gonadotrophins, ovarian steroids and ovarian oxytocin during the luteal phase of the oestrous cycle of the cow. J. Reprod. Fert. 71, $479-491$.

Wathes, D.C., \& Swann, R.W. (1982) Is oxytocin an ovarian hormone? Nature, Lond. 297, 225-227.

Watkins, W.B. (1983) Immunohistochemical localization of neurophysin and oxytocin in the sheep corpora lutea. Neuropeptides 4, 51-54.

Watkins, W.B., Moore, L.G., Fairclough, R.J., Peterson, A.J. \& Tervit, H.R. (1984a) Possible role for ovarian prostaglandin $F_{2 a}$ in stimulating luteal oxytocin release in ewes at luteolysis. J. Steroid Biochem. 20, 1507, Abstr.
Watkins, W.B., Moore, L.G., Flint, A.P.F. \& Sheldrick, E.L. (1984b) Secretion of neurophysins by the ovary in sheep. Peptides 5, 61-64.

Webb, R., Mitchell, M.D., Falconer, J. \& Robinson, J.S. (1981) Temporal relationships between peripheral plasma concentrations of oxytocin, progesterone and 13,14-dihydro-15-keto-prostaglandin $\mathbf{F}_{2 a}$ during the oestrous cycle and early pregnancy in the ewe. Prostaglandins 22, 443-451. 